\title{
Description of a New Species of the Genus Staphylococcus: Staphylococcus carnosus
}

\author{
K. H. SCHLEIFER AND U. FISCHER \\ Lehrstuhl Mikrobiologie, Technische Universität München, D-8000 Munich 2, Federal Republic of Germany
}

\begin{abstract}
From dry sausage, a new species, Staphylococcus carnosus, has been isolated and described. The new species is established primarily on the basis of its deoxyribonucleic acid-deoxyribonucleic acid hybridization relationships, its biochemical reactions, and its cell wall composition. The type strain of this species is DSM 20501.
\end{abstract}

It has been known for a long time that micrococci take part in the fermentation of dry sausage (11-13). More recent studies have shown that many of these micrococci were incorrectly identified and are in fact staphylococci $(4,14)$. One group of these staphylococci was tentatively identified as belonging to Staphylococcus simulans because they closely resembled the type strain (ATCC 27848) of $S$. simulans (4). The present communication describes this group of "S. simulans" strains as a new species of Staphylococcus, namely, $S$. carnosus.

\section{MATERIALS AND METHODS}

Strains identified as members of " $S$. simulans" were isolated from dry sausage and from a starter culture used for the production of dry sausage (Fa. Müller, Giessen, F. R. G.) by plating samples on plate-count agar or on Schleifer and Krämer's (17) selective medium for staphylococci. The other strains included in this study are listed in Table 2. All organisms, with the exception of Lactobacillus gasseri DSM 20243, were cultivated aerobically in peptone-yeast extract-glucose- $\mathrm{NaCl}$ broth (7). The strain of $L$. gasseri was grown under microaerophilic conditions in MRS medium (1). The incubation temperature was $32^{\circ} \mathrm{C}$. Carbohydrate and physiological reactions were determined by methods previously described $(7,16)$. The preparation of cell walls and the determination of the peptidoglycan type were performed as described by Schleifer and Kandler (15). Cell wall teichoic acids were extracted with $60 \%$ hydrofluoric acid. Their chemical compositions were determined by hydrolysis with $2 \mathrm{~N} \mathrm{HCl}$ at $100^{\circ} \mathrm{C}$ for $3 \mathrm{~h}$ and subsequent gas chromatography of the $\mathrm{N}, \mathrm{O}$-trifluoracetylated products. The oxidase test was carried out as described by Faller and Schleifer (3). The class of fructose-1,6biphosphate-aldolase was determined by the method of Götz et al. (5). The cytochrome pattern was elucidated as previously reported (2). The guanine-pluscytosine $(\mathrm{G}+\mathrm{C})$ content of the deoxyribonucleic acid (DNA) was determined by the thermal denaturation method of Marmur and Doty (9). Radioactive labeling of DNA and the DNA-DNA hybridization experiments were also carried out as previously described $(10,18)$.

\section{RESULTS AND DISCUSSION}

The description of the new species, based on 14 strains from dry sausages and 1 strain (no. 61) from a starter culture for dry sausages, is as follows.

Description of Staphylococcus carnosus sp. nov. (car.nó sus. L. adj. carnosus pertaining to flesh).

Cocci, 0.5 to $1.5 \mu \mathrm{m}$ in diameter, occurring predominantly in pairs and singly. Gram positive. Nonmotile. Nonsporeforming. Colonies were slightly raised, circular, smooth, slightly glistening, and usually gray-white and ranged from about 1 to $3 \mathrm{~mm}$ in diameter.

All strains grew facultatively anaerobically and produced, under anaerobic growth conditions, equal amounts of $\mathrm{D}$ - and $\mathrm{L}$-lactate from glucose. The $\mathrm{pH}$ of a peptone-yeast extractglucose broth was lowered from 6.8 to 4.2 after 2 days of growth under anaerobic conditions.

All strains grew well at 15 and $45^{\circ} \mathrm{C}$ and at $\mathrm{NaCl}$ concentrations up to $15 \%$. All strains reduced nitrate and produced acetoin. All failed to produce coagulase and to exhibit hemolysin activity. All' were negative for the oxidase test and resistant to $50 \mu \mathrm{g}$ of lysozyme per ml. Their growth was inhibited by $200 \mu \mathrm{g}$ of lysostaphin or $1.6 \mu \mathrm{g}$ of novobiocin per $\mathrm{ml}$.

All strains produced acid aerobically from glucose, fructose, mannose, mannitol, and glycerol. All failed to produce acid from xylose, sucrose, maltose, xylitol, rhamnose, turanose, raffinose, fucose, and melibiose.

Variable characters of the strains are listed in Table 1 . The peptidoglycan types of the strains were studied, and all were determined to be $\mathrm{L}$ Lys-Gly $_{5-6}$. This type of peptidoglycan was previously found in $S$. aureus, $S$. cohnii, $S$. simulans, and $S$. xylosus $(6,15)$. The $\mathrm{G}+\mathrm{C}$ contents of the DNAs of five strains were determined and were found to vary between 35 and $36 \mathrm{~mol} \%$ (Table 1).

DNA-DNA hybridization studies indicated 
TABLE 1. Variable characters of 15 strains of $S$. carnosus

\begin{tabular}{|c|c|c|c|c|c|}
\hline \multirow{2}{*}{ Strain no. } & \multirow{2}{*}{$\begin{array}{l}\mathrm{G}+\mathrm{C} \text { content of } \\
\text { DNA }(\mathrm{mol} \%)\end{array}$} & \multicolumn{3}{|c|}{ Acid (aerobically) from: } & \multirow{2}{*}{$\begin{array}{l}\text { Anaerobic fermentation } \\
\text { of glucose }(\mathrm{pH}) \text { in peptone } \\
\text { yeast extract-glucose broth }\end{array}$} \\
\hline & & Galactose & Lactose & Trehalose & \\
\hline 51 & $\mathrm{ND}^{a}$ & + & - & - & 4.3 \\
\hline 61 & 36 & + & - & + & 4.4 \\
\hline 91 & 35 & - & + & + & 4.5 \\
\hline 151 & ND & - & - & + & 4.5 \\
\hline 191 & ND & - & - & + & 4.3 \\
\hline 201 & ND & - & - & + & 4.2 \\
\hline 211 & ND & - & - & + & 4.4 \\
\hline 221 & ND & - & - & + & 4.5 \\
\hline 271 & ND & + & + & + & 4.7 \\
\hline 301 & 36 & - & - & - & 4.8 \\
\hline 311 & 35 & + & + & + & 4.7 \\
\hline 341 & ND & - & - & - & 4.7 \\
\hline 351 & ND & - & - & - & 4.6 \\
\hline 361 (= DSM 20501) & 36 & + & - & + & 4.6 \\
\hline 841 & ND & - & + & - & 4.3 \\
\hline
\end{tabular}

${ }^{a}$ Not determined.

that the strains of $S$. carnosus are closely related to one another at the species level (Table 2). The DNA homology values with other staphylococci, with the exception of $S$. simulans, were rather low (10 to $20 \%$ ) but were significantly higher than the values between the staphylococci and an unrelated gram-positive bacterium of low G $+\mathrm{C}$ content, namely, Lactobacillus gasseri DSM 20243 (Table 2). The DNA homology values (32 to $39 \%$ ) between the type strain of $S$. simulans, ATCC 27848, and the strains of $S$. carnosus are higher than those between ATCC 27848 and the other staphylococci. This indicates that $S$. carnosus and $S$. simulans are closely related to each other but not closely enough to justify their union in one species. In

TABLE 2. DNA-DNA hybridization relationships among $S$. simulans ATCC 27848, S. carnosus DSM 20501, and various other strains of staphylococci ${ }^{a}$

\begin{tabular}{|c|c|c|}
\hline \multirow[b]{2}{*}{ Source of filter-bound DNA } & \multicolumn{2}{|c|}{$\%$ relative binding of labeled DNA from } \\
\hline & $\begin{array}{l}\text { S. simulans } \\
\text { ATCC } 27848\end{array}$ & $\begin{array}{c}\text { S. carnosus } \\
\text { DSM 20501 } \\
\text { (no. 361) }\end{array}$ \\
\hline Staphylococcus simulans ATCC $27848^{b}$ & 100 & 32 \\
\hline S. xylosus DSM $20266\left(=\right.$ ATCC 29971) ${ }^{b}$ & 15 & 17 \\
\hline S. saprophyticus CCM $883(=\text { ATCC } 15305)^{b}$ & 13 & 12 \\
\hline S. cohnii DSM $20260\left(=\right.$ ATCC 29974) ${ }^{b}$ & 13 & 13 \\
\hline S. haemolyticus ATCC $20263^{b}$ & 16 & 17 \\
\hline S. hominis ATCC $27844^{b}$ & 18 & 18 \\
\hline S. epidermidis ATCC $14990^{b}$ & 20 & 20 \\
\hline S. capitis ATCC $27840^{b}$ & 16 & 15 \\
\hline S. warneri ATCC $27836^{b}$ & 10 & 12 \\
\hline S. sciuri ATCC $29062^{b}$ & 11 & 10 \\
\hline S. intermedius CCM $5739(=\text { ATCC } 29663)^{b}$ & 13 & 14 \\
\hline S. aureus ATCC $12600^{b}$ & 17 & 14 \\
\hline S. carnosus no. 61 & 39 & 105 \\
\hline S. carnosus no. 301 & 37 & 103 \\
\hline S. carnosus no. 311 & 38 & 101 \\
\hline S. carnosus DSM $20501^{c}$ (no. 361) & 38 & 100 \\
\hline L. gasseri DSM $20243^{d}$ & 4 & 4 \\
\hline
\end{tabular}

a The percentage of radioactivity bound in the heterologous reaction was normalized to the percentage of radioactivity bound in the homologous reaction and expressed as a homology value. Optimal reassociation conditions were employed corresponding to approximately $25^{\circ} \mathrm{C}$ below the thermal melting point of the DNA $\left(0.45 \mathrm{M} \mathrm{NaCl}\right.$ plus $0.045 \mathrm{M}$ sodium citrate adjusted to $10 \%$ formamide, $\left.58^{\circ} \mathrm{C}\right)$.

b Type strain (19).

c Type strain (designated in this paper).

$d$ Type strain (8). 
TABLE 4. Characters useful in the separation of $S$. curnosus from other staphylococci“

\begin{tabular}{|c|c|c|c|c|c|c|c|c|c|c|c|}
\hline Character & S. carnosus & S. aureus & S. simulans & S. xylosus & S. cohnii & $\begin{array}{l}\text { S. sapro- } \\
\text { phyticus }\end{array}$ & $\begin{array}{l}\text { S. haemo- } \\
\text { lyticus }\end{array}$ & S. warneri & S. hominis & $\begin{array}{l}\text { S. epider- } \\
\text { midis }\end{array}$ & S. capitis \\
\hline Coagulase & $-b$ & + & - & - & - & - & _ & - & - & - & - \\
\hline Phosphatase & + & + & $( \pm)$ & $(+)$ & $(-)$ & $(-)$ & $(-)$ & $(-)$ & $(-)$ & + & $(-)$ \\
\hline Hemolysis & - & $(+)$ &, \pm- & $(-)$ & $(-, \pm)$ & - & $(+)$ &, \pm- & $(-)$ &, \pm- & $(-)$ \\
\hline Growth on $15 \% \mathrm{NaCl}$ & + &, \pm- & $( \pm)$ & $(+, \pm)$ & $( \pm,+)$ &, \pm+ & $( \pm,-)$ & $( \pm,-)$ & - & - &, \pm- \\
\hline Nitrate reduction & + & + & + & $(+)$ & - & - & $(+)$ & $(-)$ & $(+, \pm)$ & $(+, \pm)$ & $(+)$ \\
\hline Acetoin production & + & + & $(-)$ &, \pm- &,+ \pm & $(+)$ &,+ \pm & + & $\mathbf{v}$ & + & v \\
\hline $\begin{array}{l}\text { Acid (aerobically) trom } \\
\text { Maltose }\end{array}$ & - & + &,- \pm & $(+)$ & $( \pm,+)$ & + & + &,+ \pm & + & + & _ \\
\hline Lactose & $(-)$ & $(+)$ & + & $\mathrm{v}$ & $(-)$ & $(+)$ &,-+ & $(-)$ & $\mathbf{v}$ & $(+)$ & _- \\
\hline Sucrose & - & + & + & + & $(-)$ & + & + & + & + & + & + \\
\hline Resistance to novobiocin ${ }^{c}$ & - & - & - & + & + & + & - & - & - & - & - \\
\hline
\end{tabular}

a With the exception of $S$. carnosus, the data are taken from Kloos and Schleifer (6).

${ }^{b}$ A single symbol denotes a frequency of 90 to $100 \%$; parentheses around symbols denote a type frequency of 70 to $89 \%$; two symbols are listed for a character when either type has a frequency below $70 \%$, but together the frequencies equal 80 to $100 \%$. + , Positive; \pm , weak; - , negative; $v$, variable $(+$, \pm , and - ).

c Minimal inhibitory concentration $\geq 3.1 \mu \mathrm{g} / \mathrm{ml}$.
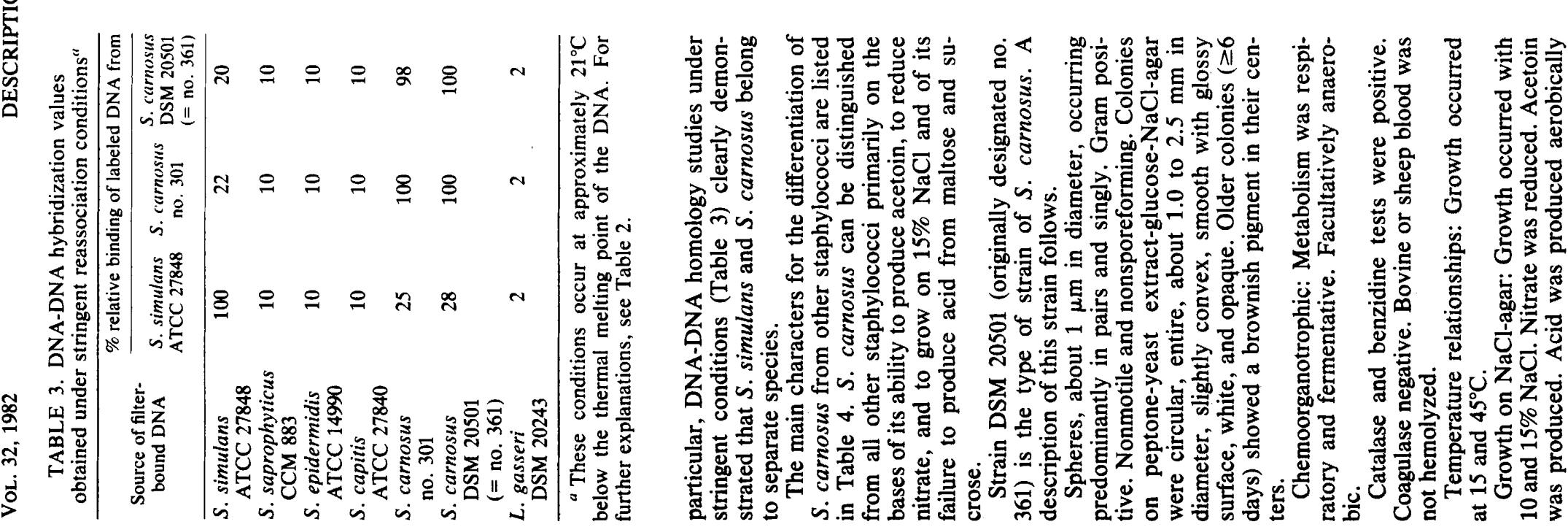
from glucose, fructose, galactose, mannose, ribose, trehalose, mannitol, and glycerol. No acid from xylose, sucrose, maltose, lactose, xylitol, rhamnose, turanose, raffinose, fucose, or melibiose. Susceptible to lysostaphin $(100 \mu \mathrm{g} / \mathrm{ml})$ and novobiocin $(1.6 \mu \mathrm{g} / \mathrm{ml})$.

Fructose-1,6-biphosphate aldolase: class $I$.

Peptidoglycan type: L-Lys-Gly ${ }_{5-6}$.

Cell-wall teichoic acid composition: Glycerol, glucose, galactosamine, and traces of glucosamine were present.

\section{$\mathrm{G}+\mathrm{C}$ content of DNA: $36 \mathrm{~mol} \%$.}

\section{REPRINT REQUESTS}

Address reprint requests to: Dr. K. H. Schleifer, Lehrstuhl Mikrobiologie, Technische Universität München, Arcisstrasse 21, D-8000 Munich 2, Federal Republic of Germany.

\section{LITERATURE CITED}

1. DeMan, J. C., M. Rogosa, and M. E. Sharpe. 1960. A medium for cultivation of lactobacilli. J. Appl. Bacteriol. 23:130-135.

2. Faller, A. H., F. Götz, and K. H. Schleifer. 1980. Cytochrome patterns of staphylococci and micrococci and their taxonomic implications. Zentralbl. Bakteriol. Parasitenkd. Infektionskr. Hyg. Abt. 1 Orig. Reihe C 1:26-39.

3. Faller, A. H., and K. H. Schleifer. 1981. Modified oxidase and benzidine tests for the separation of staphylococci from micrococci. J. Clin. Microbiol. 13:1031-1035.

4. Fischer, U., and K. H. Schleifer. 1980. Zum Vorkommen der Gram-positiven, katalase-positiven Kokken in Rohwurst. Fleischwirtschaft 60:1046-1051.

5. Götz, F., Nürnberger, E., and K. H. Schleifer. 1979. Distribution of Class I and Class II D-fructose-1 .6-biphosphate aldolase in various Gram-positive bacteria. FEMS Microbiol. Lett. 5:253-257.

6. Kloos, W. E., and K. H. Schleifer. 1975. Isolation and characterization of staphylococci from human skin. II. Descriptions of four new species: Staphylococcus warneri, Staphylococcus capitis, Staphylococcus hominis, and Staphylococcus simulans. Int. J. Syst. Bacteriol. 25:62-79.

7. Kloos, W. E., T. G. Tornabene, and K. H. Schleifer. 1974.
Isolation and characterization of micrococci from human skin, including two new species: Micrococcus lylae and Micrococcus kristinae. Int. J. Syst. Bacteriol. 24:79-101.

8. Lauer, E., and O. Kandler. 1980. In Validation of the publication of new names and new combinations previously effectively published outside the IJSB. List no. 4. Int. J. Syst. Bacteriol. 30:601.

9. Marmur, J., and P. Doty. 1962. Determination of the base composition of deoxyribonucleic acid from its thermal denaturation temperature. J. Mol. Biol. 4:109-118.

10. Meyer, S. A., and K. H. Schleifer. 1978. Deoxyribonucleic acid reassociation in the classification of coagulasepositive staphylococci. Arch. Microbiol. 117:183-188.

11. Niinivaara, F. P., and M. S. Pohja. 1956. Über die Reifung der Rohwurst. I. Mitt.: Die Veränderung der Bakterienflora während der Reifung. Z. Lebensm. Unters. Forsch. 104:413-422.

12. Niinivaara, F. P., and M. S. Pohja. 1957. Über die Reifung der Rohwurst. II. Mitt.: Die Beschreibung der aus Rohwurst isolierten Bakterienstämme und ihre Bedeutung beim Reifungsproze $\beta$. Z. Lebensm. Unters. Forsch. 106:187-196.

13. Niinivaara, F. P., and M. S. Pohja. 1957. Erfahrungen bei der Herstellung von Rohwurst mit Bakterienreinkulturen. Fleischwirtschaft 9:789-790.

14. Rheinbaben, K.v., and R. Hadlok. 1979. Gattungsdifferenzierung von Mikroorganismen der Familie Micrococcaceae aus Rohwürsten. Fleischwirtschaft 59:1321-1324.

15. Schleifer, K. H., and O. Kandler. 1972. Peptidoglycan types of bacterial cell walls and their taxonomic implications. Bacteriol. Rev. 36:407-477.

16. Schleifer, K. H., and W. E. Kloos. 1975. Isolation and characterization of staphylococci from human skin. I. Amended descriptions of Staphylococcus epidermidis and Staphylococcus saprophyticus and descriptions of the three new species: Staphylococcus cohnii, Staphylococcus haemolyticus, and Staphylococcus xylosus. Int. J. Syst. Bacteriol. 35:50-61.

17. Schleifer, K. H., and E. Kramer. 1980. Selective medium for isolating staphylococci. Zentralbl. Bakteriol. Parasitenkd. Infektionskr. Hyg. Abt 1 Orig. Reihe C 1:270-280.

18. Schleifer, K. H., S. A. Meyer, and M. Rupprecht. 1979. Relatedness among coagulase-negative staphylococci. Deoxyribonucleic acid reassociation and comparative immunological studies. Arch. Microbiol. 122:93-101.

19. Sherman, V. B. D., V. McGowan, and P. H. A. Sneath (ed.). 1980. Approved lists of bacterial names. Int. J. Syst. Bacteriol. 30:225-420. 